\title{
Reinventing the heights: the origins of rockclimbing culture in Australia
}

\author{
Michael Meadows* \\ School of Humanities, Griffith University, Nathan Campus, Nathan, Brisbane 4111, Australia
}

\begin{abstract}
Australian rockclimbing culture and climbers have been imagined in a particular way with the late nineteenth- and early twentieth-century press playing a key role. Australian landscapes, including mountains, were incorporated into Indigenous cosmology for millennia before Aboriginal people discovered Europeans. But with the colonial invasion, the very nature of the landscape in the new colony meant that climbing culture was bound to take on a different persona from its European antecedent and undergo a rethinking or reinvention process. Figuring strongly in this discursive reconstruction was the particular geography of one region in Australia - southeast Queensland - with its diverse collection of volcanic peaks within range of a major population centre, along with a climate that encouraged the emergence of a set of complementary leisure activities. This article explores the emergence of rockclimbing culture in Australia from a range of often competing and contradictory discourses - Aboriginal cosmology, a unique landscape, the influence of the European idea of climbing and charismatic, visionary individuals. From the turn of the twentieth century, the role of local newspapers and magazines was a crucial element in this imagining process creating briefly a space for female climbers that has only recently been reclaimed. From the late 1880s, and particularly during the 1920s and 1930s, press reports of climbing and associated activities offered new ways of conceptualizing mountains and their place in shaping Australian culture.
\end{abstract}

Climbing a mountain has become a way to understand self, world, and art. It is no longer a sortie from but an act of culture. (Solnit 2000, 113)

\section{Introduction}

There is little scholarly literature on the history of climbing in Australia, possibly because it has been seen as more culturally peripheral than its European and American incarnations and other local popular outdoor activities, such as organized sport and surfing. This is odd, considering that one of the most identifiable landforms in eastern Australia is the 3500kilometre Great Dividing Range. This complex chain of mountains, hills, cliff lines and valleys has been both a practical and intellectual barrier from the time of European invasion. Climbing it - or perhaps more accurately, crossing it - was the impetus for much of the early exploration in the colony (Steele 1972). It seems incomprehensible that this significant mountain landscape did not impact in some way on Australian culture. Abrahamsson (1999, 51) reminds us that cultural groups transform the physical environment into landscapes through the use of symbols that bestow different meanings on the same physical objects, a theme taken up by Bonyhady and Griffiths $(2002,6)$ who suggest: 'Landscape does not just shape language; the land itself is transformed by words, phrases and ways of telling'. Despite this, Australia has been overwhelmingly imagined in terms of 'the bush' and/or 'a wide brown land', effectively ignoring the influence of mountain landscapes and associated

*Email: m.meadows@griffith.edu.au 
cultural activities. This is the result of an almost exclusive analytical focus thus far on literary and visual images (Bonyhady 1985, 2000; Whitlock and Carter 1992; Bonyhady and Griffiths 2002; Horne 2005). I will argue that the textual discourses in local newspapers - all but ignored in scholarly considerations of Australian landscapes thus far - played a critical role, primarily because of their accessibility and pervasiveness. And it is through such popular discursive formations that mountains, and more importantly, their representations and the activities associated with them, played - and continue to play - a central important role in imagining Australia (Anderson 1984).

The emergence of Australian climbing culture was influenced by the unique geographical make-up of particular regions - specifically, the igneous outcrops and mountains of southeast Queensland and the seemingly endless sandstone cliffs of the Blue Mountains. But importantly, ideas of mountains and their place in Australian culture found their way into the imagining process primarily through representations of these landscapes and the associated activities by climbers in local newspaper articles and images. This 'authorization' by the press resulted in the discursive incorporation of mountain landscapes and associated leisure activities into the everyday culture and life in Australia. In the 11 years from 1927, the Brisbane Courier and the Queenslander alone featured around 150 articles many accompanied by photographs - on climbing exploits of a passionate southeast Queensland-based group, dubbed 'The Crowd'. In Queensland, and to some extent in New South Wales and Tasmania, the idea of climbing was enshrined in popular culture during the 1920s and 1930s. For the rest of Australia, it would remain a post-war phenomenon.

The space that women created in this activity - still regarded as a high-risk activity ended with the Second World War and was not to re-emerge for another 50 years. Apart from the extraordinary achievements of some notable individuals such as US Brisbanebased climber, Coral Bowman and Victoria's Louise Shepherd during the 1980s, the reengagement of a number of women with regular rockclimbing activity is a relatively recent phenomenon.

\section{Imagining the heights}

Australian rockclimbing culture has emerged in a particular way and in a particular context. All landscape features, including mountains, were incorporated into Indigenous cosmology for millennia before Aboriginal people discovered Europeans (Steele 1984). There seems little doubt that Aboriginal people could have climbed most, if not all, of the mountains in Australia - if they needed or wanted to. It is Indigenous people's interest in climbing that is more problematic (Tuan 1974; Child 1998; Meadows 2002). During a return visit to this country in 1993, one of the doyens of Australian rockclimbing, John Ewbank, alluded to the importance of context in considering Australian climbing culture. Drawing on Indigenous concepts of the 'sacred', he argued that an acknowledgement of what made a particular location 'sacred' for Indigenous people - ritual, belief and tradition - was also central to understanding rockclimbing culture. While acknowledging the clear differences in interpretation and meaning between Indigenous and non-Indigenous cosmologies, he suggested an analogy: that the act of climbing could be seen as 'turning a piece of rock into a sacred site' and 'it is then that we superimpose special values on it, even if these values are comprehensible only to other climbers'. He concluded:

I think it is becoming increasingly important for climbers to see cliffs and mountains within the context of a broader landscape and to realise that these outcrops, these 'bones of the planet' are already sacred, just as they are to many people other than climbers. (Ewbank 1993, emphasis in original) 
However, the different sets of values involved here create an obvious conflict: the very process of climbing in some areas deemed to be of significant importance to Indigenous people pays scant respect to their cultural significance. This is perhaps most evident in the very public pleas by the central Australian Anangu (Pitjantjatjara) for decades for people to not climb Uluru because of its sacred status (Parks Australia 2009). It is apparent, too, in other creation stories of high places (Tuan 1974, 70; Boardman 1982, 181; Steele 1984).

From its earliest emergence as a recreation, 'the unruly assemblages recognised as climbing' today find themselves straddling leisure and sport in the panoply of popular cultural activities (Rossiter 2007, 304). The term 'rockclimbing' now refers to a wide range of activities which could range from visiting a local gym, 'bouldering' on small rock outcrops, 'traditional' or 'trad' climbing outdoors on cliffs and peaks or 'sport' climbing and its variations. Rockclimbing emerged in Europe as a pastime, separate from its predecessor - mountaineering - late in the nineteenth century. Described by some as a form of "vertical colonialism', it was a peculiarly European phenomenon with a strong British influence (Donnelly 1982; Morgan 1994; Nettlefold and Stratford 1999, 132). But there are many other 'historically produced and socially constructed' elements that have defined both the idea and the practice of rockclimbing in Australia and beyond (Bricknell 1994, 45).

Climbing in its many forms has become a community and communal cultural practice one might even argue a culture industry - with its own language, symbols and style, 'signified in both epic and environmental terms' with a distinctly 'playful' element (Abramson and Fletcher 2007). Rockclimbing incorporates 'constructed and fluid' notions of identity elements identified in Bennett's $(1999,614)$ concept of neo-tribalism, although he developed the idea to explain the relationships between youth, music and style in the UK. The relatively recent scholarly attention paid to rockclimbing offers a range of variations on this broad theme. For example, Williams and Donnelly $(1985,14)$ identify the importance of the individual as the 'potential agent of change' in rockclimbing practice, operating within the social constraints of local climbing cultures. And while Rapelje (2004) enlists the notion of 'sub-world groups' to explore the nature of climbing communities in North America, a more functional view is offered by climber-writer, Lito Tejada-Flores. In perhaps one of the most cited essays on climbing, 'Games Climbers Play', written for Ascent magazine in 1967, he muses:

Climbing is not a homogeneous sport but rather a collection of differing (though) related activities, each with its own adepts, distinctive terrain, problems and satisfactions, and perhaps most important, its own rules. (Tejada-Flores 1967)

Building on this broad idea, albeit from a leisure studies perspective, Stebbins' $(2007,5)$ concept of 'serious leisure' is helpful, defining it in terms of participants engaging in leisure activities with the aim of 'acquiring and expressing a combination of its special skills, knowledge and experience'. But it is perhaps closer to home where the most appropriate theorizing of rockclimbing practice in Australia is taking place. Kiewa (2001, 380) identifies not only the importance of the creation of personal space as a central defining element in climbers' leisure experiences, but also that 'identity forms a major motivation for behaviour'. Building further on the idea of serious leisure, Rossiter (2007, 303) - who, like Kiewa, is a climber - argues that rockclimbing, along with other adventurous activities, is 'usually understood as a way of being in space or as a mode of experiencing or dwelling within natural spaces'. She continues:

Alternatively, though, climbing may be understood as the production of new spaces through moving encounters between the human and various nonhumans. These are complex spaces that are at once technocultural, material, natural, disciplinary, resistant, and discrete yet constantly changing. (Rossiter 2007, 303) 


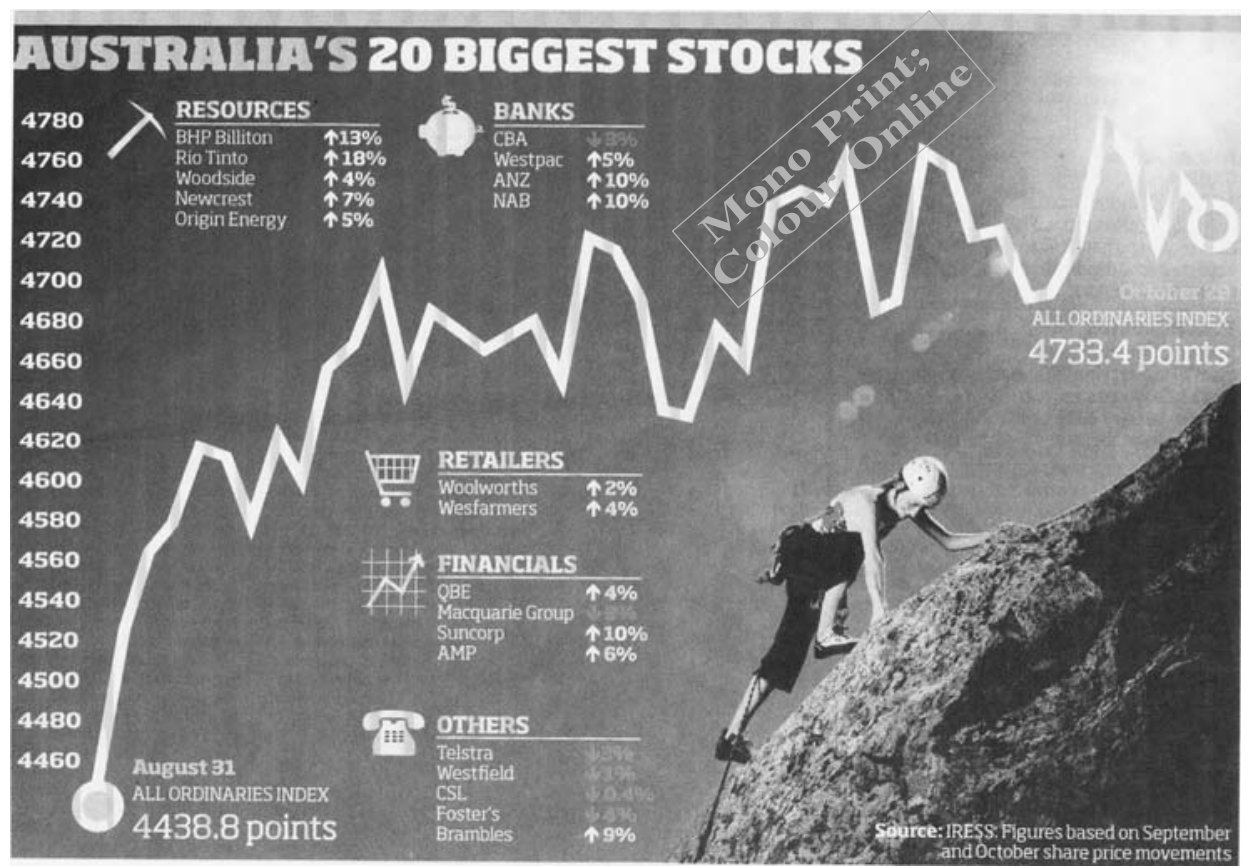

Figure 1. An unusual alliance of women, rockclimbing and the Australian Stock Market. (CourierMail 2011, p. 39).

While the history of climbing within a masculine framework continues its cultural influence in the new millennium, there have been - and continue to be - some significant challenges to that (Robinson 2002; Rossiter 2007). Images of female climbers abound, perhaps predictably, on the covers of the Australian climbing magazine, Rock. Perhaps less predictably, they have been enlisted in advertisements for a diverse range of organizations - including airlines, insurance companies, a manufacturer of contact lenses - and even to illustrate a newspaper article on stock market growth

Considering climbing as a gendered space is not a new phenomenon. Prominent female climbers such as Elizabeth Burnaby LeBlond were active in late nineteenth-century Europe, at a time when the mountains were considered no place for women. Three years after the Ladies Alpine Club was formed in England in 1907, Australia's first mountaineer Freda Du Faur became the first woman to climb Aoraki-Mt Cook. Over the next few years, this exceptional young climber made several more first ascents in the New Zealand Alps, including the first Aoraki-Mt Cook/Mt Tasman traverse (Du Faur 1915; Irwin 2000). But it was on the volcanic peaks of southeast Queensland that Australia's first mass rockclimbing movement was born with women playing a central role in it. Despite women in significant numbers reclaiming a space in Australian rockclimbing culture from the early 1990s - albeit primarily in urban climbing gyms - women's place on the heights remains contentious, situated, as many are, between discourses such as 'mountaineering and motherhood' (Frohlick 2006). And while this term was coined from the perspective of mountaineering, female rockclimbers have expressed similar views (Jackie Kiewa, Interview, 6 May 2004, Brisbane; Bernie Manly, Telephone Interview, 13 February 2004). 'Spatial information' such as climbing guidebooks are also part of the process of the conversion of 'space into place' (Nettlefold and Stratford 1999, 137-138), but accessing climbing landscapes 
involves moving across a range of texts: indigenous histories; environmental writings; scientific discourses; tourist brochures; and more recently, regulations governing access to specific climbing locations (Meadows 2002; Taylor 2006, 213; Qurank 2011).

It is difficult to say categorically why the earliest significant rockclimbing activity in Australia was confined to southeast Queensland and to a lesser extent, the Blue Mountains and the Tasmanian wilderness. In Queensland, it may have been quite simply synchronicity: a juxtaposition of easily accessible peaks near a thriving population centre (Brisbane), a charismatic 'leader' (Bert Salmon), an enthusiastic cohort and year-round good climbing weather! Climbing activity in the Blue Mountains seems to have been confined to a small circle of friends of Dr Eric Dark living in the immediate vicinity (E. Lowe 1931; Clio 1990). The very low population of Tasmania, the weather and the difficulty of merely reaching peaks there, let alone climbing them, most likely mitigated against widespread activity. What emerges from the earliest known Tasmanian accounts of climbing between the wars and post-Second World War is a sporadic quest for summits - mingled with bushwalking and hunting cultures - rather than a climbing movement (Emmett 1935; Luckman 1949; Frauca 1958).

\section{The emergence of climbing as leisure}

There are many Indigenous stories about mountains in Australia based on strong cultural beliefs that discourage or forbid people from climbing them (Wise 1916; Steele 1972). However, there are contradictory accounts of Aboriginal ascents of many high places, well before Europeans set eyes on the colonial 'mountains of the mind' (Lang 1861; Brisbane Courier 1872; Pears 1923; MacFarlane 2003). Exploration was the dominant frame through which mountains were viewed by Europeans in the colony of New South Wales for more than half a century before the first claimed ascents - as a leisure practice - were made. The very knowledge of the existence of the European Alps meant that mountains in Australia would inevitably become a lure for settlers (Horne 1991). This process was triggered in 1813 when explorers Blaxland, Lawson and Wentworth found a way across the Great Divide west of Sydney. Most, if not all, of this early exploration relied heavily on 're-discovering' existing Aboriginal tracks through the mountains that had existed for probably thousands of years (McKenna 2002).

Newspaper accounts of mountaineering exploits in the European Alps began to appear regularly in the colonial press from the 1870 s, and a new reason for climbing mountains in the colony began to emerge. It was no longer necessary to justify ascents in terms of exploration or scientific discovery. One of the earliest published newspaper items in the Australian press on mountaineering, 'The Mania For Alpine Climbing', was a report of a disaster on Mont Blanc (Queenslander 1866, 2). It was followed five years later by a brief account of what was probably the first European ascent of Mt Warning, known by the local Bandjalang people as Wollombin. Botanist, author and landscape gardener William R. Guilfoyle was one of the four young men who spent three and a half days climbing to the summit where they became 'embosomed in mountains of indescribable splendour' (Queenslander 1871, 11). The appropriation of these spaces as places in popular culture is evident in the earliest accounts of climbing activity.

From the mid 1880s, articles on mountaineering and climbing were regular fare in Queensland newspapers. This was accompanied by a broad redefinition of European ideas of leisure and recreation in their various forms in settled Australia (Hamilton-Smith 1998). In 1886, the first extensive body of writing about local climbing as a recreational activity was published. In a three-part newspaper feature, Brisbane-based adventurer Thomas 
Welsby recounted his exploits climbing in the Glasshouse Mountains, making what was possibly the first European ascent of one of the peaks, Tibrogargan. Keen to announce his success to a waiting throng at a guest house more than 300 metres below, Welsby lit a fire on the summit. By the time he had descended, the mountain was ablaze in the twilight:

The moon did not rise until 8 o'clock. By that time, the place was all aglow, and as the moon rose from out of the eastern sky and threw its flooding rays over the hilltops, the blending of the two lights mellowed the scene with a 'dim religious' colouring of beauty none of us can ever forget. (Welsby 1886, 933)

Despite his contribution to plant species that require intense heat to regenerate, the practice of setting summits alight is a recurring one in Australian climbing history as is the incorporation of such places into the popular imagination. Around this time, there were reports of claims of first ascents in tropical North Queensland, including all of the peaks on Hinchinbrook Island in 1881 (Meston 1894) and in the Bellenden Ker Range - the highest in the state (Queenslander 1887). Journalist, newspaper editor, politician and Protector of Aborigines Archibald Meston made numerous expeditions to North Queensland and the voluminous collection of writings from this time represents, arguably, the first significant body of journalism focussing on wilderness to be published in Australia. Meston wrote in the style of the romantics, evident in this description of the summit of Queensland's second-highest peak, Mt Bellenden Ker, in 1889:

We were silent in the awful presence of that that tremendous picture that had laid there unaltered since Chaos and the Earthquake painted it in smoke and flame and terror in the dark morning of the world! It was a hall of the Genii of the Universe, the Odeon of the eternal gods with its immortal floor paved with the green mosaic of land and ocean, and overhead the arched blue roof flashing in diamonds and prismatic radiance to the far skyline on the edge of the dim horizon. (Meston 1889a, 7)

Meston's collection of writings about mountains and his ascents inscribes them with characteristics of the sublime, while at the same time 'normalizing' them as culturally relevant places. Both Welsby and Meston acknowledged an Aboriginal presence in the landscape in their writings - but with qualification. Meston (1889b) made a spirited call for the retention of Aboriginal place names for the North Queensland mountains and it is only in recent times that the Noongyanbudda Ngadjon people's original names for Mt Bartle Frere (Chooreechillum) and Mt Bellenden Ker (Wooroonooran) have been revived (Wet Tropics Aboriginal Plan Project Team 2005).

In southern Queensland in the following year, 26-year-old immigrant Norwegian naturalist Carstens Egeberg Borchgrevink joined a local man to make what they believed would be the first European ascent of Mt Lindesay, unaware that it was actually the third. Reports of the climb in the Queenslander featured the first-known published image of climbers in action in Australia by artist E. Bihan. Perhaps influenced by Meston's early descriptions, depictions of mountains in the colonial press at this time were clearly influenced by romantic notions of 'the sublime'. But at the same time, the frequency of climbing accounts and ensuing debates in letters to the editor of the Brisbane Courier, in particular, suggested an engaged public.

One of the last great challenges for climbers in southeast Queensland - the trachyte spire of Coonowrin (Crookneck) in the Glasshouse Mountains - was first scaled in 1910 by 23 -year-old Henry Mikalsen who had grown up in the shadow of the mountain. It has been identified by some as the beginning of rockclimbing 'as a pastime' in Australia (Lack 1938). Two years later, sisters Sara, Jenny and Etty Clark were the first-known women to reach the summit. Two of the sisters had cycled 80 kilometres from Brisbane two days earlier. They wore 'voluminous gym clothes' for the climb and cycled back to Brisbane on 


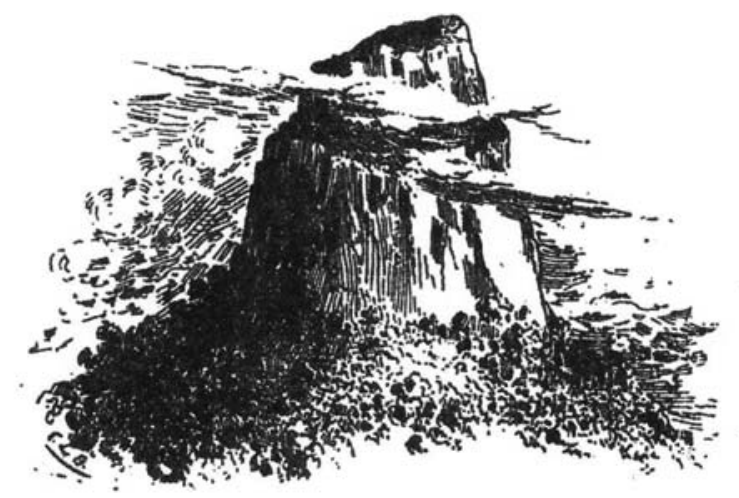

Figure 2. Artist E Bihan's impression of Mount Lindesay, accompanying an article of an early ascent of the peak by Norwegian explorer Carstens Borchgrevink. (Queenslander 1890, p. 189).

the same day (Whitehouse 1966, 77). Full-page newspaper coverage of their adventure featured a series of photographs - the first-known climbing photographs published in Australia (Rowley 1912, 13). The following year, Thomas Welsby featured the photographs again in his book, The Discoverers of the Brisbane River - the first publication of its type in the country to include a significant section on climbing, along with his sailing adventures in Moreton Bay (Welsby 1913).

By the closing decades of the nineteenth century, climbing and leisure in Australia were closely allied, although this 'act of culture' was restricted to individuals or small local groups (Solnit 2000). But change was in the air.

\section{Climbing with the 'spiritual father'}

Albert Armitage Salmon, dubbed the 'spiritual father' of Queensland climbing (Benuzzi 1953), made his first ascent in 1923. Three years later, he formed a 'mountaineering club' in southeast Queensland - dubbed 'The Crowd' - incorporating both climbing and walking with a penchant for the most challenging ascents then known. It was the first of its kind in Australia and was indicative of a growing desire by a small number of leisured citizenry to push the limits of the possible (Lack 1938). Salmon made many ascents of the peaks in southeast Queensland over the following decade and soon introduced women to the joys of mountaineering, Queensland style (Queenslander 1927; Easton 1928; Salmon 1928).

The Queensland-based climbers generally eschewed the use of rope (and any other form of artificial aid) except as 'moral support'. It seems likely that Salmon was influenced by the ethics of early British gritstone climbers, such as Dean Frankland and Fergus Graham, renowned for their preference for soloing climbs in the Lake District around this time, along with approaches adopted by the American environmentalist-climber John Muir (Smith 1978; White 1999; Meadows 2002).

The Blue Mountains, west of Sydney, were also a focus of climbing activity for a small cohort of friends during the 1930s with the charismatic Dr Eric Dark as the main protagonist. He and Salmon were the most influential in fostering an Australian climbing culture during this 'golden era', although the two did not meet until 1934. Dark was the first in Australia to use a rope for protection in the European sense, but he and his climbing partners were not averse to using what they called 'an unethical instrument' - a two-metre long ice axe with a deeply curved pick and a 
notch to hold the rope where the shaft entered the head - that they used to haul themselves past difficult sections of a climb (Clio 1990, 18). Their first major achievement was an ascent near the Arethusa Falls in the Grose Valley in 1931, duly reported by the Sydney Mail (E. Lowe 1931).

Eric Dark and his cohort held to British climber Albert Mummery's edict that a rope should never be used for direct aid on a climb (Clio 1990, 18). Dark was a socialist and began climbing before Salmon, a staunch monarchist, and while they climbed contemporaneously, their methods could not have been more different. Dark was the

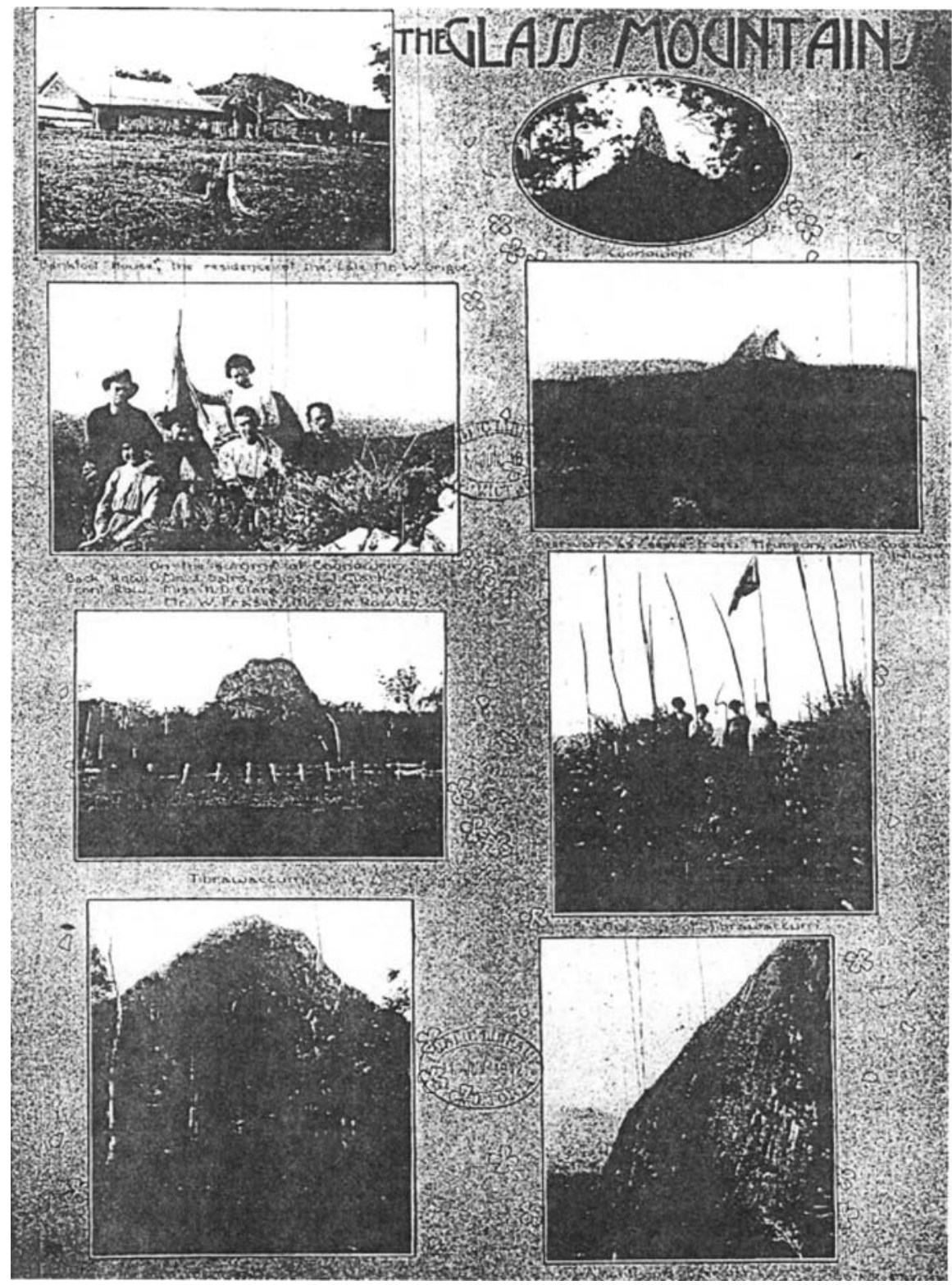

Figure 3. The first climbing photographs published in the Australian press: the Clark sisters make the first female ascent of Crookneck in the Glasshouse Mountains near Brisbane. (Queenslander 8 June 1912, p. 27). 


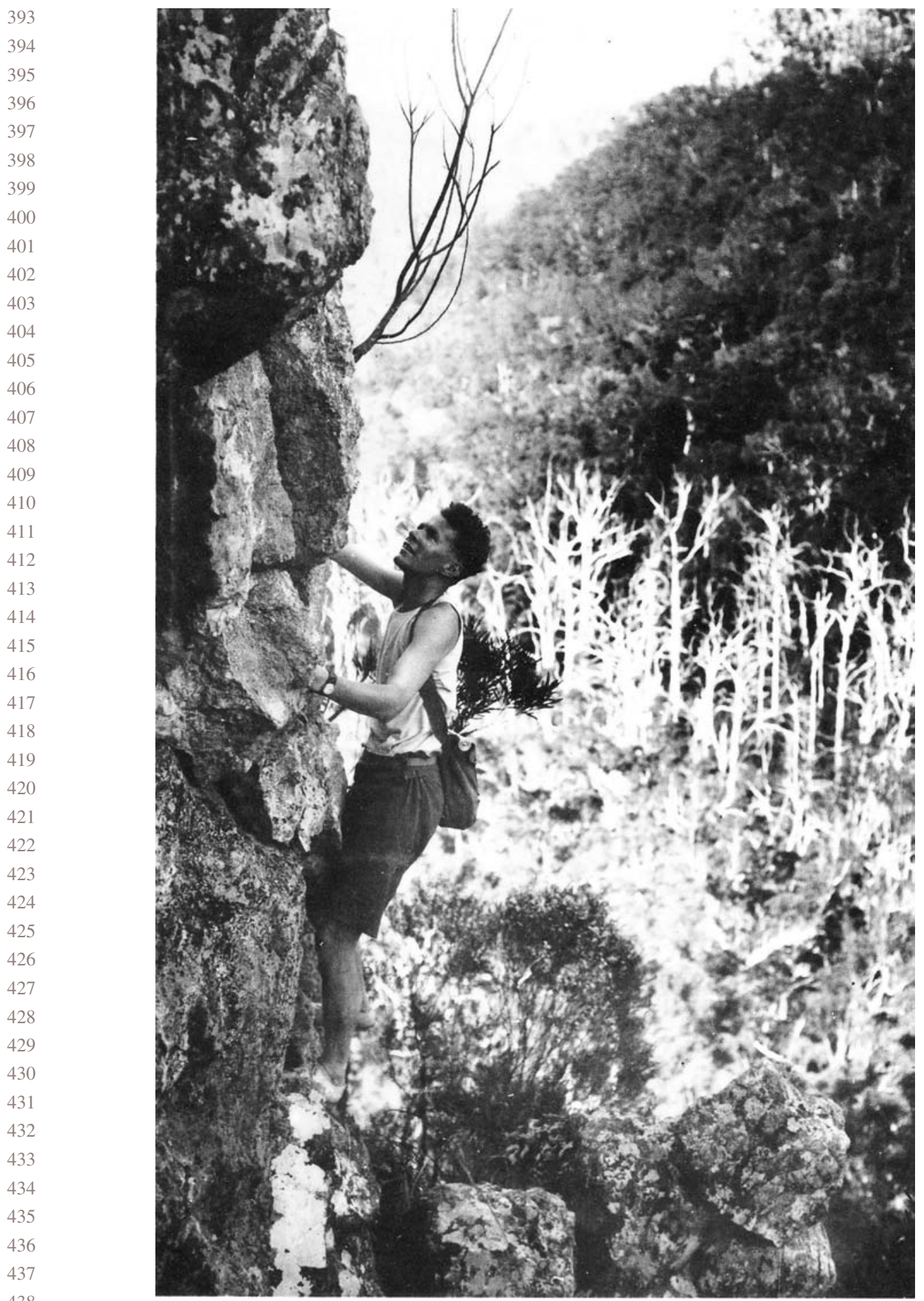

Figure 4. The 'spiritual father' of Queensland climbing, Bert Salmon, on the first ascent of Egg Rock in southern Queensland in 1927. (A. A. Salmon collection). 
inaugural president of the Blue Mountaineers, a climbing club formed in 1929 and based, as the name suggests, in the Blue Mountains. It also carried the nickname of the 'Katoomba Suicide Club' (Allen 1963; Clio 1990). The club was active throughout the 1930s but it did not attract the level of popular support evident in Queensland.

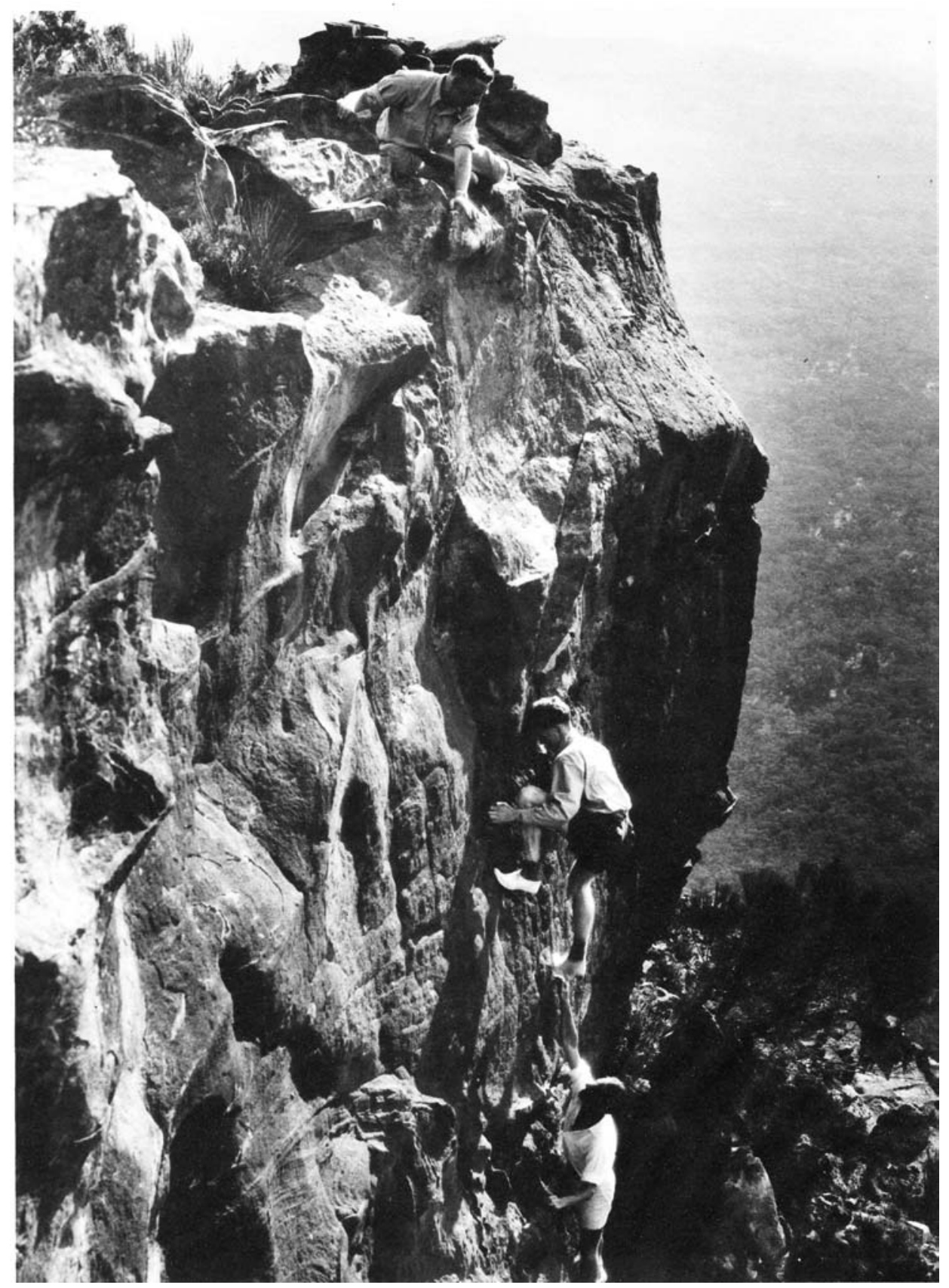

Figure 5. Eric Dark (top) watches Queensland climber George Fraser make the first unroped ascent of the Fly Wall at Katoomba in the Blue Mountains in 1934. (A. A. Salmon collection). 


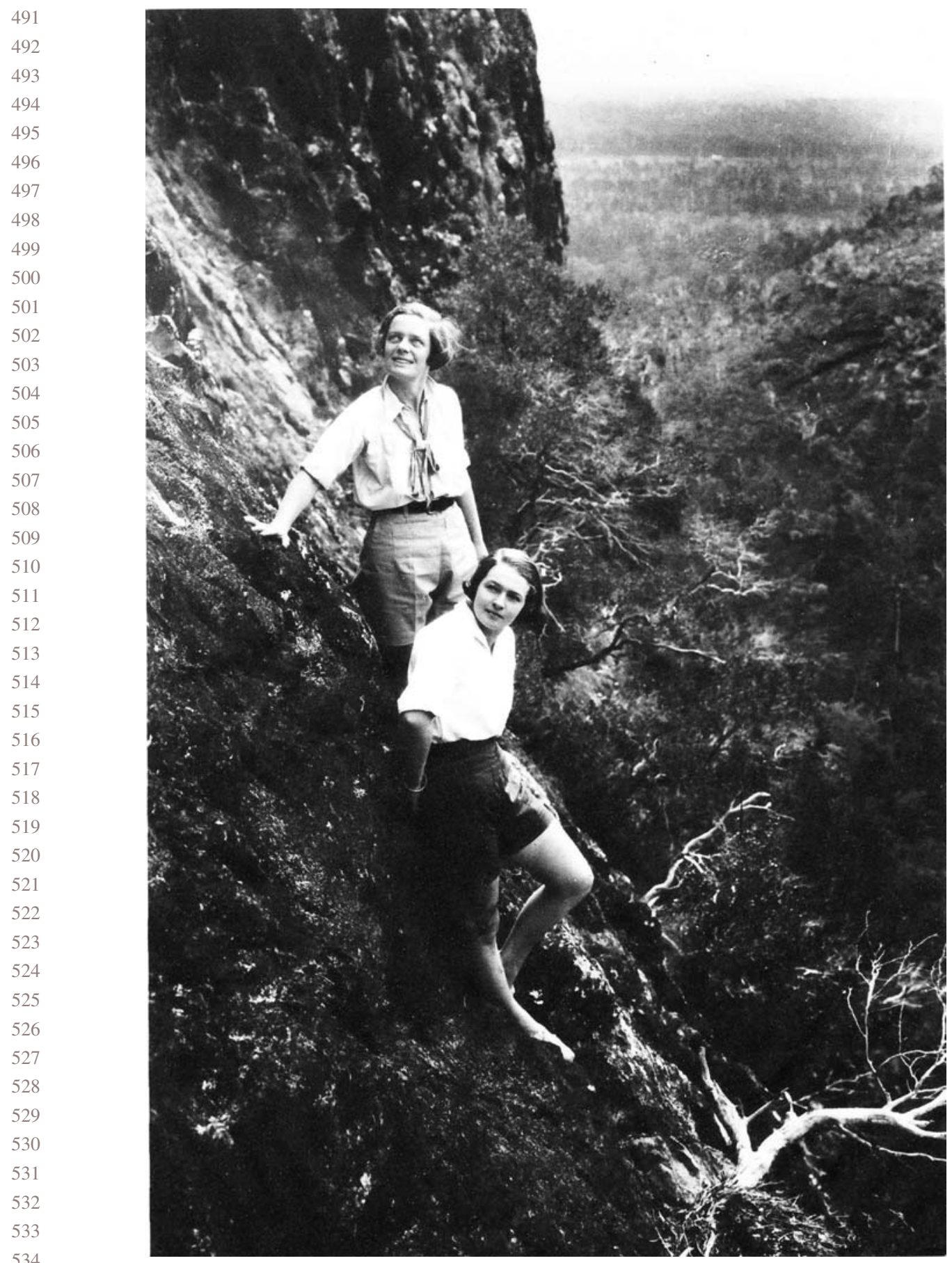

Figure 6. Queensland climbers Jean Easton (top) and Muriel Patten on the east face of Tibrogargan 
Nevertheless, the Blue Mountains was the only other place in Australia where a significant level of climbing was taking place at this time, although it was confined to a small cohort centred on Eric Dark and his wife, novelist Eleanor Dark. Regardless, it was promoted as 'a health-giving sport for women' in a Sydney magazine (N. Lowe 1931, 22).

In January 1934, 16 climbers from Queensland made a pilgrimage south to the Blue Mountains, meeting up with their New South Wales' counterparts for Australia's first-ever climbing meet. Within days, 21-year-old Muriel Patten became the first woman to climb the First Sister, applying her tried and tested Queensland climbing style, making the ascent unroped. Newspapers in Brisbane (Courier-Mail 1934) and the Blue Mountains were impressed:

Miss Muriel Patten, a petite and daring Brisbane girl, claims a record: that she is the only woman to scale the first of the Three Sisters. One section of this climb is extremely difficult and hazardous: particularly for a lady. (Katoomba Daily 1934, 1)

For his next climb, Eric Dark took the visitors to the testing 'Fly Wall' - a 10-metre high vertical cliff that aspiring members of the Blue Mountaineers had to climb to gain admission to the club. Much to Dark's consternation, Salmon and another of the Queenslanders, George Fraser, scaled the wall refusing to use a safety rope from above (Lack 1938, 3). Despite the interaction at Katoomba, neither Salmon nor Dark changed their approaches to climbing. In 1936, Dr Eric Dark and a barefoot Dorothy English - a 'qualified masseuse and remedial gymnast' - made the first ascent of Crater Bluff in the Warrumbungles Range in western New South Wales (Butler 1992, 64). They lit a small fire on the summit to announce their success to the world but like Thomas Welsby's experience on Tibrogargan, 50 years earlier, it spread and soon the entire summit was ablaze. It was probably the hardest climb in Australia at that time.

By the end of 1935, the spate of climbing activity north of the border, along with an ever-increasing supply of photographs, prompted the Queenslander Annual to run a feature article entitled, 'Let's Go Mountaineering'. Climber-journalist Nora Dimes captured the

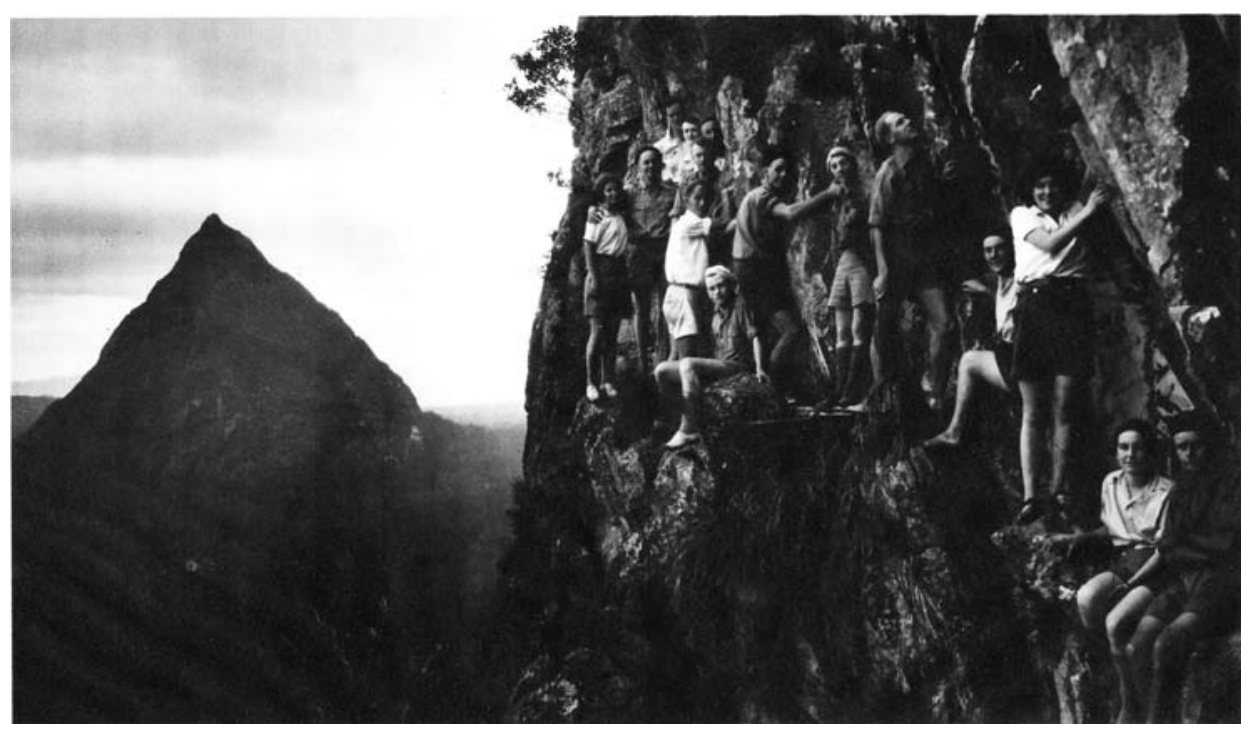

Figure 7. A record 15 members of 'The Crowd' on a narrow ledge on the south side of Crookneck in the Glasshouse Mountains in 1933. (Cliff and Lexie Wilson collection). 


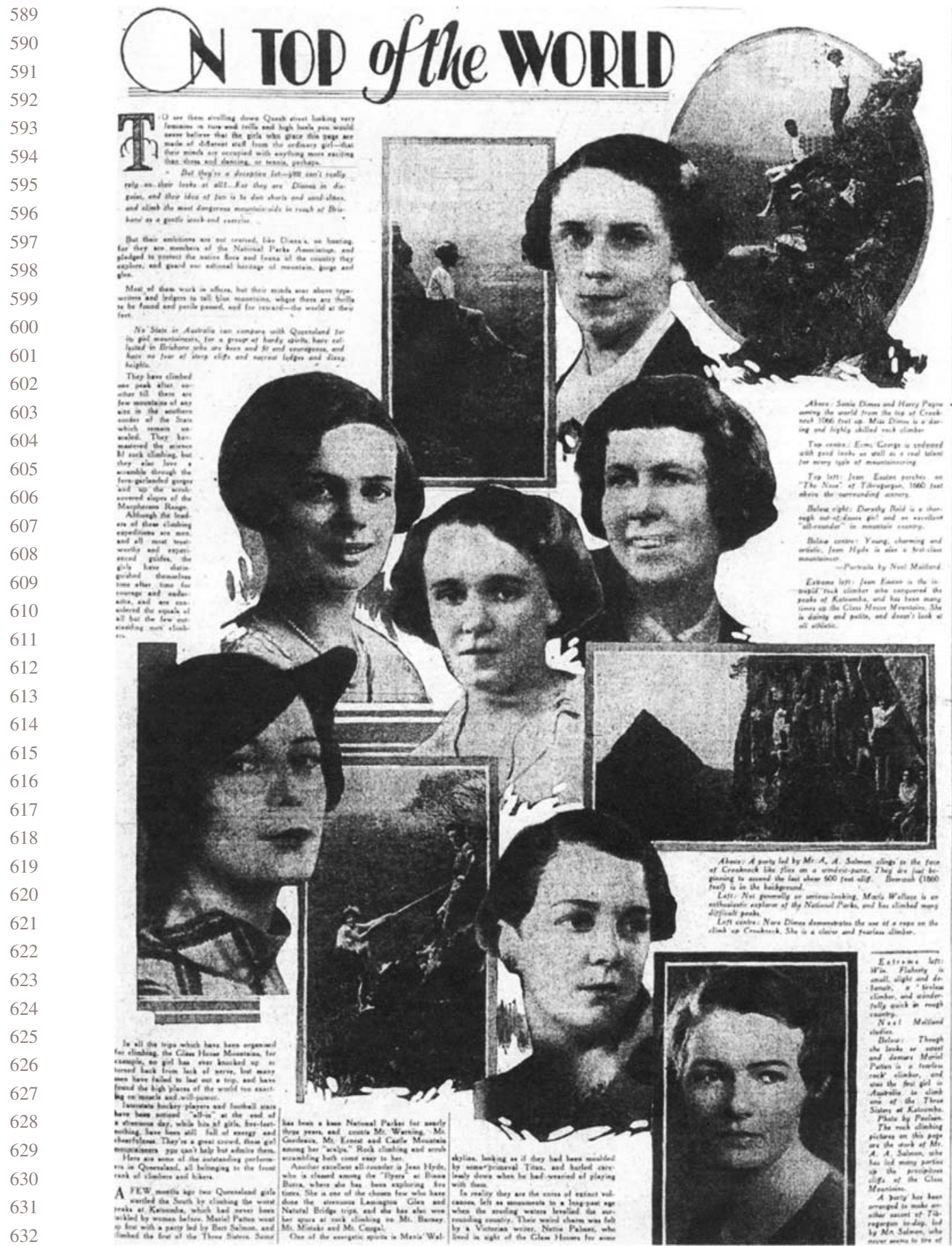

Figure 8. Newspaper coverage of Queensland's female climbers. (Truth 29 July, 1934, p. 25). 
competitive spirit of the age in a tongue-in-cheek description of climbing in Queensland as 'mountaineering on molehills' $(1935,18)$. Women made up a substantial proportion of climbers in Queensland from the late 1920s until the Second World War, sometimes outnumbering their male companions on climbs (Meadows, Thomson, and Stewart 2000). Their abilities were clearly recognized, as this excerpt from Walkabout magazine suggests:

Surprise that women should care to tackle such climbs has been expressed, but in the view of Mr A. A. Salmon, of the Department of Agriculture and Stock, who has led climbs to the top of each Glass House peak more than 20 times, women are good climbers, and as novices give less trouble than men. (Brammall 1939, 40)

The involvement of significant numbers of women in climbing in Queensland was unique - nowhere else in the country was this evident. Climbing parties of 10-20 people were common with a record 33 men and women climbing the difficult south face of Coonowrin on one occasion in 1933. The achievements of Jean Easton and Muriel Patten, in particular, received significant coverage in local newspapers and magazines. One newspaper article featured profiles of the 'top 15' female climbers at the time, concluding that 'the Queensland girls have left the rest of Australia far behind in this exacting and exciting sport' (Truth 1934, 25).

Despite the hyperbole of some accounts, the Queensland climbing cohort seemed to place a strong emphasis on the social - creation of personal space and notions of identity (Kiewa 2001) - rather than the technical side of climbing. This is evident in the multitude of photographs that survive and newspaper accounts from the period in question. The early 1930s was also a time when a hiking boom in the UK and Australia enabled women to escape to 'the bush' - arguably one of the few non-chaperoned spaces easily accessible. At the end of such 'mystery' train rides, the mountains were never far away in southeast Queensland. Perhaps this was an important element that helped create the conditions of existence for the first mass climbing movement in the country with a significant involvement by women in creating a 'less gendered space', or, perhaps, a less masculine space (Rossiter 2007). But importantly, Rossiter (2007, 303) suggests that such dichotomous conceptualizations - feminine-masculine, for example - may be too simplistic because they fail to encompass the contextual complexity in which climbing occurs: 'the moving encounters between the human, non-human natures and other nonhumans that come into being through rockclimbing'. Such a perspective further problematizes a conclusion as to why particular climbing movements in Australia started in particular places at particular times.

Accounts of climbers' experiences as represented in newspapers and magazines for a decade from the late 1920s imagine rockclimbing as part of everyday, albeit 'edgy', culture. These accounts in the Queensland press - as was the case elsewhere in Australia at this time - paralleled the emergence of a mediatized national parks' movement, further framing rockclimbing activity as (albeit serious) leisure and unproblematically 'authorizing' it as an integral part of popular culture. The first 'wild' national parks in the world were proclaimed in Australia, again providing contextual support for the acceptance of rockclimbing activities in such places as 'normal' (Hamilton-Smith 1998, 45).

\section{Conclusion}

By the late 1940s and early 1950s, there were few unclimbed peaks or large rock outcrops left in Australia. This period was marked by the expansion of rockclimbing and bushwalking clubs, and appearance of the first climbing route guides, coinciding with articles about climbing being banished from the pages of the popular press. It was a 
significant discursive shift in ways of constituting the landscape through rockclimbing as a cultural activity. In a sense, control of the process of representation was relegated to editors of outdoors' club newsletters and magazines with mainstream newspapers now interested in climbing only when it complied with post-war news values that tended to centre on nation-building and sensationalism. Post-war rockclimbing remained a relatively peripheral 'act of culture' (Solnit 2000) in Australia until the late 1980s/early 1990s when globalization and the spread of indoor climbing centres triggered an explosion in the number of participants, capturing the attention of the popular media once again and enabling women to reclaim their place on the heights to an extent.

Throughout the 1950s, rockclimbing clubs - along with bushwalking clubs expanded across the country, particularly at universities, paralleling a similar 'youth movement' in Europe (Donnelly 1982). After the Second World War, it was the introduction of modern climbing technologies from Europe, and later, the United States, that had a more powerful impact on the evolution of Australian rockclimbing culture and associated perceptions of mountain landscapes. The so-called 'clean climbing' movement in Australia during the late 1960s - rejecting the use of damaging pitons and bolts in favour of more environmentally friendly protective devices - reflects this perceptive shift. It was accompanied by often heated ethical debates between individuals (and even interstate rivalries!), which inevitably invoked and influenced perceptions of the landscape and our place in it. It reminds us of the complexity of climbers' experiences and the danger in relying on dualisms to explain them (Rossiter 2007). A spiritual connection with landscape is something that is not universal among rockclimbers but the contradictions continue: for example, many of the tree-climbing protesters in continuing Tasmanian anti-logging campaigns are climbers. Arguably, the connection with place is becoming less dominant as rockclimbing genres (gym and sport climbing, bouldering, etc.) become further divorced from bushwalking, the most popular entry point for many into the sport up until the mid-1970s. Improved communication has enhanced the globalizing forces that continue to influence rockclimbing and climbers internationally with a diversification of Australian climbing into varied forms by the end of the 1980s. Although this has continued to distance many of activities called 'rockclimbing' from their original close association with ideas of landscape and the environment, their varied influence on perceptions of place remains (Abrahamsson 1999, 51; Meadows 2002; Abramson and Fletcher 2007). Climbers now make headlines most often either when they are involved in injury or death, or when they reach well-known (usually Himalayan) summits.

Climbing as a cultural practice emerged in Australia from a complex range of often competing and contradictory discourses - Aboriginal cosmology, differing landscapes, the influence of the European idea of climbing, gendered spaces and charismatic, visionary individuals. The role of local newspapers and magazines in Queensland, in particular, was a crucial element in the imagining process, particularly from the turn of the twentieth century. From the late 1880s and during the 1920s and 1930s, regular articles and images in the press offered audiences new ways of conceptualizing mountains, the men and women who climbed on them and their contribution to making Australian culture.

\section{Acknowledgements}

A special thanks to research assistant Robert Thomson who has done much of the archival work for this research. I also thank the anonymous reviewers who offered their valuable insights that helped sharpen my focus. 


\section{Notes on contributors}

Michael Meadows began rockclimbing as a teenager in southeast Queensland and returned to the sport after an absence of almost 20 years in the late 1990s. His passion for climbing and bushwalking has recently merged with a new academic interest in the role of early newspapers in representing landscape and the environment in Australia.

\section{References}

Abrahamsson, Kurt Viking. 1999. "Landscapes Lost and Gained: On Changes in Semiotic Resources." Human Ecology Review 6 (2): 51-61.

Abramson, Allen, and Robert Fletcher. 2007. "Recreating the Vertical: Rock-Climbing as Epic and Deep Eco-Play." Anthropology Today 23 (6): 3-7.

Allen, Bryden. 1963. The Rock Climbs of New South Wales. Sydney: Sydney Rockclimbing Club.

Anderson, Benedict. 1984. Imagined Communities: Reflections on the Origin and Spread of Nationalism. London: Verso.

Bennett, Andy. 1999. "Subcultures or Neo-Tribes? Rethinking the Relationship Between Youth, Style and Musical Taste." British Sociological Journal 33 (3): 599-617.

Benuzzi, Felice. 1953. "Scarponate Australiane: Sulle Glass House Mountains." Lo Scarpone March 1.

Boardman, Peter. 1982. Sacred Summits: A Climber's Year. Seattle, WA: The Mountaineers.

Bonyhady, Tim. 1985. Images in Opposition: Australian Landscape Painting 1801-1890. Melbourne: Oxford University Press.

Bonyhady, Tim. 2000. The Colonial Earth. Melbourne: Miegunyah Press.

Bonyhady, Tim, and Tom Griffiths. 2002. Words for Country: Landscape and Language in Australia. Sydney: University of New South Wales Press.

Bricknell, Louise. 1994. "Leisure? According to Who?" In Leisure: Modernity, Postmodernity, and Lifestyles, edited by I. Henry, 39-52. Brighton: Leisure Studies Association.

Brisbane Courier. 1872. "Ascent of Mount Lindsay." Brisbane Courier, May 18.

Butler, Dot. 1992. The Barefoot Bushwalker. Sydney: ABC Enterprises.

Child, Greg. 1998. Postcards from the Ledge: Collected Mountaineering Writings of Greg Child. Seattle, WA: The Mountaineers.

Clio. 1990. "Portrait of a Pioneer." Rock, January-June, 18-21.

Courier-Mail. 1934. "Scaled One of the 'Three Sisters': Miss Muriel Patten's Feat.” Courier-Mail, February 6.

Dimes, Nora. 1935. "Let's Go Mountaineering." Queenslander Annual.

Donnelly, Peter. 1982. "Social Climbing: A Case Study of the Changing Class Structure of Rock Climbing and Mountaineering in Britain.” In Studies in the Sociology of Sport, edited by A. O. Dunleavy, A. W. Miracle, and C. R. Rees, 13-28. Fort Worth: Texas Christian University Press.

Du Faur, Freda. 1915. The Conquest of Mount Cook and Other Climbs: An Account of Four Seasons' Mountaineering on the Southern Alps of New Zealand. London: George Allen \& Unwin.

Easton, Jean. 1928. "Tibrogargan: One of the Glass Houses." Queenslander, June 28.

Emmett, E. T. 1935. "Climbing the Frenchman's Cap.” Walkabout, August 1, 39-40.

Ewbank, John. 1993. "Ironmongers of the Dreamtime." Keynote address delivered at The Escalade Festival, Mount Victoria, Blue Mountains, New South Wales, April.

Frauca, Harry. 1958. "The Hartz Mountains National Park.” Walkabout, January 1, 31-33.

Frohlick, Susan. 2006. "Wanting the Children and Wanting K2: The Incommensurability of Motherhood and Mountaineering in Britain and North America in the Late Twentieth Century." Gender, Place and Culture 13 (5): 477-490.

Hamilton-Smith, Elery. 1998. “. From Cultural Awakening to Post-Industrialism: The History of Leisure, Recreation and Tourism in Australia.” In Time Out? edited by H. Perkins, and G. Cushman, 34-50. Auckland: Addison Wesley Longman.

Horne, Julia. 1991. "Travelling Through the Romantic Landscapes of the Blue Mountains." Australian Cultural History 10: 84-98.

Horne, Julia. 2005. The Pursuit of Wonder: How Australia's Landscape was Explored, Nature Discovered and Tourism Unleashed. Carlton: Miegunyah Press.

Irwin, Sally. 2000. Between Heaven and Earthy: The Life of a Mountaineer, Freda du Faur. Hawthorn: White Crane Press. 
Katoomba Daily. 1934. "Brisbane Girl Climbs the Sisters! Is it a Record?" Katoomba Daily, January 28.

Kiewa, Jackie. 2001. "Control Over Self and Space in Rockclimbing." Journal of Leisure Research 33 (4): $363-382$.

Lack, Clem. 1938. "Mountain Climbers of Queensland." Sunday Mail, July 10.

Lang, John Dunmore. 1861. Queensland, Australia. Brisbane.

Lowe, Eric. 1931. "Ascent of the Arethusa Falls." Sydney Mail, September 16.

Lowe, Nina. 1931. "Rock-Climbing: A Health-Giving Sport for Women." Australian Woman's Mirror December 22.

Luckman, J. S. 1949. "Federation Peak, Tasmania." Walkabout, April 1, 18-28.

MacFarlane, Robert. 2003. Mountains of the Mind: A History of a Fascination. London: Granta Books.

McKenna, Mark. 2002. Looking for Blackfellas' Point: an Australian History of Place. Sydney: University of New South Wales Press.

Meadows, Michael. 2002. "The Changing Role of Queensland Newspapers in Imagining Leisure and Recreation.” E-journalism, Accessed November 2, 2011. http:// ejournalist.com.au/v1n2/MEADOWS.pdf

Meadows, Michael, Robert Thomson, and Wendy Stewart. 2000. "Close to the Edge: Imagining Climbing in Southeast Queensland." Queensland Review 7 (2): 67-84.

Meston, Archibald. 1889a. "Exploring the Bellenden Ker II." Brisbane Courier, May 25.

Meston, Archibald. 1889b. "Exploring the Bellenden Ker." Brisbane Courier, May 18.

Meston, Archibald. 1894. "Hinchinbrook in 1881." Telegraph, January 6.

Morgan, Dan. 1994. "It Began with the Piton. The Challenge to British Rock Climbing in a PostModernist Framework." In Leisure: Modernity, Postmodernity, and Lifestyles, edited by Ian Henry, 341-342. Brighton: Leisure Studies Association.

Nettlefold, Peter A., and Elaine Stratford. 1999. "The Production of Climbing Landscapes-AsTexts.” Australian Geographical Studies 37 (2): 130-139.

Parks Australia. 2009. "Uluru-Kata Tjuta National Park Note: Please Don't Climb.”, Department of Sustainability, Environment, Water, Population and Communities' website. Accessed November 25, 2011. http://www.environment.gov.au/parks/publications/uluru/pn-pleas e-dont-climb.htm

Pears, P. W. 1923. "Mt Lindesay. Letter to the Editor." Brisbane Courier, November 22.

Queenslander. 1866. "The Mania For Alpine Climbing." December 29.

Queenslander. 1871. "The Southern Border." April 1.

Queenslander. 1887. "Mount Bellenden-Ker." July 9.

Queenslander. 1927. "Ascent of Crookneck: Thrilling Trip.” December 29.

Qurank. 2011. "Access Issues." Queensland Cranking [Climbing] Online Community website. Accessed April 8, 2011. http://www.qurank.com/

Rapelje, Brandon Wayne. 2004. "August. Rock-Climbing Sub-Worlds: A Segmentation Study." Master of Science diss. Texas A\&M University.

Robinson, Victoria. 2002. Men, Masculinities and Rock Climbing, Everyday Cultures Working Papers No. 5. Milton Keynes: Open University.

Rossiter, Penelope. 2007. "On Humans, Nature and Other Nonhumans." Space and Culture 10 (2): 292-305.

Rowley, George. 1912. "A Week-End at Glass-House Mountains: Successful Ascent of Coonowrin." Brisbane Courier and Observer, June 1.

Salmon, Albert Armitage. 1928. "Captain Cook's Glasshouses." Queenslander, March 1.

Smith, K. 1978. "Epitaph to a Cragsman." Climber and Rambler, February, 1-26.

Solnit, Rebecca. 2000. Wanderlust: A History of Walking. New York: Viking.

Stebbins, Robert A. 2007. Serious Leisure: A Perspective for Our Time. London: Transaction Publishers.

Steele, J. G. 1972. The Explorers of the Moreton Bay District 1770-1830. St Lucia: University of Queensland Press.

Steele, J. G. 1984. Aboriginal Pathways in Southeast Queensland and the Richmond River. St Lucia: University of Queensland Press.

Taylor, J. 2006. "Mapping Adventure: A Historical Geography of Yosemite Valley Climbing Landscapes." Journal of Historical Geography 32: 190-219. 
Tejada-Flores, Lito. 1967. “Games Climbers Play.” Ascent Accessed August 8, 2001. http://web.mit. edu/lin/Public/climbing/Games_Climbers_Play.txt 23-25.

Truth. 1934. "Modern Maids of the Mountain: On Top of the World." Truth, July 29.

Tuan, Yi-Fu. 1974. Topophilia: A Study of Environmental Perception, Attitudes, and Values. New York: Columbia University Press.

Welsby, Thomas. 1886. "To the Top of the Glass Mountains: No. 1." Queenslander, June 12.

Welsby, Thomas. 1913. The Discoverers of the Brisbane River. Brisbane.

Wet Tropics Aboriginal Plan Project Team. 2005. Caring for Country and Culture: The Wet Tropics Aboriginal Cultural and Natural Resource Management Plan. Cairns: Rainforest CRC and FNQ NRM.

White, Graham. 1999. Sacred Summits: John Muir's Greatest Climbs. Edinburgh: Cannongate.

Whitehouse, Fred W. 1966. "Early Ascents of the Glasshouses." Heybob 8: $72-77$.

Whitlock, Gillian, and David Carter. 1992. Images of Australia. St Lucia: University of Queensland Press.

Williams, T., and P. Donnelly. 1985. "Subcultural Production, Reproduction and Transformation in Climbing." International Review for the Sociology of Sport 30 (3): 3-16.

Wise, Reginald. 1916. "A Climb Up Coonowrim (sic)." Queenslander, September 23. 